\title{
Perception of Young University Students about Acts of Corruption
}

\author{
Ivett Reyes Guillén*, Raúl Vázquez Gutiérrez, Socorro Fonseca Córdoba, María Angelina \\ Villafuerte Franco, Gustavo Zárate Vargas \\ Autonomous University of Chiapas, Mexico
}

*Corresponding Author: Ivett Reyes Guillén, Autonomous University of Chiapas, Mexico

\begin{abstract}
This article presents and analyses the results of a study carried out at the Autonomous University of Chiapas, Faculty of Law, with the objective of knowing the perception of young university students regarding the acts of corruption. Also, explore common corruption practices. The findings are relevant considering that future professionals identify in their immediate environment acts and actors with corrupt practices that have become naturalized and that locate Mexico in one of the first places in international ranking. The results also indicate the institutionalization of corruption and the lack of control of these acts. Another important fact is that within the social actors identified as corrupt are the politicians, police officers and lawyers who occupy the first three sites (executors of laws) and not far, fourthly, to religious representatives.
\end{abstract}

Keywords: Corruption, perceptions, youth, university, Chiapas Mexico

\section{INTRODUCTION}

The corruption concept is defining it as "the abuse of any position of power, public or private, in order to generate an undue benefit at the expense of collective or individual welfare" (Casar, 2016). This definition, as well as the consequences of these acts, leave us a complex, systemic, structural, historical and multi causal panorama, which makes the object of study a necessity of multi and interdisciplinary approach.

Global corruption is a problem experienced by all countries on a spatial or temporal scale, and even in relation to the scope of this in the various orders of the system. Because of this, and the complex conceptualization of corruption, perceptual differences, the secret of the act, is difficult to mediate.

For Latin America, corruption is a current issue, historically it has remained a relevant problem. Despite how difficult it is to measure corruption, there are parameters and international studies that have maintained Latin America and the same to Mexico, as countries where corruption has been one of the characteristics that have made us stay in the first places of most rankings.

Despite this, the international treaties on corruption that Mexico has signed, as well as the laws on transparency issued and more recently the creation of the National Anti-corruption System (NAS), the perception on this phenomenon has not improved in Our Country (CICC, 1996; ONU, 2003)

According to Latinobarometro 2017, Mexico is located within the five countries with the highest degrees of corruption in Latin America and 59\% of respondents misjudged the government's fight against corruption. Likewise, data from the Global barometer of corruption 2017, place Mexico with the highest rate of bribes in the Latin American and Caribbean region and 61\% of Mexicans surveyed believe that corruption has increased (CL, 2017).

At the time of dealing with the issue of corruption, we necessarily talk about the characteristics of this according to the perception of the population; We also talk about how we are working to control this series of events that leave high economic, moral and civil costs in a country, region or the world.

Let's review some of the civil actions that are gradually generating change store duce or eliminate corruption:

- The speed and breadth of information that reaches the population; In this the mass media and the Internet play a very important role. 
- The dissolution of the impunity pacts, acts of corruption can no longer be saved by legal privileges.

- Imprisonment of former governors, these public servants gradually cease to enjoy this broad impunity and the people themselves demand the corresponding legal actions in view of the lack of transparency or legality of the acts while they govern.

- National Anti-Corruption System (NAS); This system is a mechanism of laws and institutions, which promotes the coordination of federal, state and municipal authorities, incorporating citizen participation to prevent, investigate and punish administrative misconduct and the facts of Corruption.

How is corruption perceived? As we mentioned earlier, corruption is acts that are developed globally, is independent of the poverty or wealth of a country; It does not even depend on the culture of each country or region. However, about studies on perception of corruption measured by Transparency International, the index of Perception of corruption (IPC) indicates that Latin America and Africa are the most affected regions (Transparency International, 2018).

One of the possible explanations is aimed at the strength of democratic institutions. In Latin America, although we have democratic political systems that, to a greater or lesser extent, operate in the electoral system for some decades, with elections and alternating power between parties, institutions are often fragile and Subject to political manipulation. And this political-economic plot in countries of these regions, the population perceives in a tangible way corrupt acts and even the consequences that emanate from them.

Education, values, the economy of the families, the nature of the human being, impunity, the normalization of acts of violence and corruption are also factoring that directly influence the presence and increase of these acts at the global level. In addition, it is important to mention that there are social actors and specific acts that are classified as corrupt, others classified as possibly corrupt and others as non-corrupt even when they are. In other words, there is a scale of measurement of corrupt actors and acts within the population's perceptions.

Therefore, in the present study, the main objective was to identify the perception of actors and acts of corruption by university students in the process of training in the area of law future lawyers, how They perceive corruption. Emphasizing precisely the strictest discipline within the world of jurisprudence, and the profession with the greatest stigma of corruption.

\section{RESEARCH METHOD}

Population and sample. University students of the Faculty of Law of the Autonomous University of Chiapas. Sampling was random and under informed consent of the participants. The sample of $n=$ 107 regular students from different semesters.

To determine the sample size, it was decided to use a confidence level of $95 \%$ and a precision of $5 \%$. Considering that in our case the population is finite, we use the following equation to obtain the necessary number of students in the sample.

$n=\frac{N \cdot Z^{2} \cdot p \cdot(1-p)}{(N-1) \cdot e^{2}+Z^{2} \cdot p \cdot(1-p)}$

Where:

$n=$ Sample size.

$p=$ Proportion to estimate.

$Z=$ Number of a normal distribution associated with a desired confidence level.

$e=$ Maximum acceptable relative error

An instrument of opinion was applied with nine items with scale of self-created answers and general data of the interviewee.

\section{RESUlTS AND ANALYSIS OF INVESTIGATIONS}

\subsection{General Data of the Population Interviewed}

- $58 \%$ correspond to female gender and $42 \%$ to male.

International Journal of Humanities Social Sciences and Education (IJHSSE) Page 87 
- $32 \%$ attend the sixth semester of the law degree; $17 \%$ in the second semester; $15 \%$ the tenth; $3 \%$ first semester; $11 \%$ in the fifth semester; $5 \%$ eighth semester; $4 \%$ seventh semester.

- Average age of 21 years.

- Place of origin, 25\% Tuxtla Gutierrez, 19\% San Cristobal de Las Casas, 8\% Comitan; 6\% Tapachula; 39\% of various municipalities in the state of Chiapas. 3\% corresponds to other states of the Mexican Republic such as Puebla, Oaxaca and Tabasco.

In this case it is important to contextualize about the conditions that Chiapas holds as federal entity of Mexico, place where the present study was carried out. It is one of the states with the highest marginalization and poverty in the country, paradoxically to the conditions it holds in terms of cultural, biological and geographical richness. According to INEGI data, the population in extreme poverty in Chiapas has remained over the last 8 years, tending to average deficiencies in 3.9 in 2010 to 3.5 for 2016, varying slightly, as well as the moderate poverty conditions deficiencies of 2.4 to 2.0 in the same period. Percentage of the population with lower income than the minimum welfare line is $49.9 \%$ in the last data of INEGI (INEGI, 2016).

\subsection{Concept of Corruption, Frequencies and Social Actors}

Of those interviewed, $36 \%$ believe that corruption is a process of decay and deterioration of the moral and political order of society; The remainder, $64 \%$, define corruption as the violation of an obligation on the part of a public official or a public service provider in order to obtain a personal benefit in the form of money or gifts from the person who bribes or deceives.

In the study "Perceptions of corruption in Mexico City predisposition to the corrupt act?" (Castillo y Guerrero, S/f) when they were told to identify corruption, opinions are divided between standards transgression and moral appreciations, something very similar to what was found in our study.

In relation to the institutions where more acts of corruption are carried out in order frequency we have $(78 \%)$ :

- First, to the instances of government (any level)

- Followed by the school

- In third place the structures within the political parties

- In the Instances of the private sector

- In the church

It is important to revise that secondly, they consider the school as one of the institutions where acts of corruption are mostly carried out. If we consider that their immediate environment, who offers their own or close experiences is the one they refer to, it is then that in their lifetime of university students, of the law degree, they recognize these sites as highly corrupt after the Government institutions.

This information is complemented by the following list of acts of corruption where they point out in three sites of six, common practice in the school: presentation of medical evidence, copying on exams and the absence of teachers in their classroom hours. The interesting thing is that the corrupt acts obey the figure of the student and not the teacher, except in one case. Later we will see that even the image of the teacher is in position number seven on the list of the most corrupt professions.

It is then that the list of these different actions of corruption is as follows (81\%):

- Altering the electricity meter

- Presentation of false medical proofs

- Altering scales in the market

- Copy on a test

- Pass the traffic light in red/high

- Absence of teachers in their class hours without any justification

However, according to the Occupations and professions, the interviewees enlisted of greater to lesser presence of corruption as follows (95\%): 
- Politician

- Police officer

- Lawyer

- Priest

- Builder

- Medical

- Teacher

- Doctor

- Housewife.

Within this list, the politician appears as the main corrupt social actor and even when he is commonly related to the figure of the lawyer, he appears in place number four. Historically the politician has been a figure labeled as corrupt, however, at present to be political does not need school level, moral solvency, or social delivery and is shown precisely as part of the social disorder that is experienced at the national level and Regional.

This has an impact when it comes to linking this figure as corrupt as politicians are elected officials who enact and enforce laws, as well as make decisions about the distribution and execution of public resources. This certainly requires a thorough analysis as the corrupt figures are the elected and tolerated during their management despite the check of corrupt acts in many cases.

To this state of changes in the social order, changes in the religious order are added, changes in the way in which society perceives religion, builds it and exposes it. In the present study and specifically in this list of corrupt social figures or actors, the priests take place number five. Just one place after the lawyers.

Lastly, the figure of the housewife is located, to whom the majority (98\%) consider them not corrupt, except for a $2 \%$ that they consider that if they carry out acts of corruption within their functions.

This result is also like what the studio of Arturo del Castillo and Manuel Alejandro Guerrero (S/f) mentions about where it occurs and who are the actors of the bite. The first answer is that the bite occurs mainly in the police and/or public servants.

This is corroborated at the time of expounding that of the interviewees who consider relating to acts of corruption within the daily life:

- $61 \%$ say they ask for money to expedite bureaucratic paperwork in government offices

- And a high 39\% offer money to expedite bureaucratic paperwork in government offices

The spaces where they consider that there is more corruption are precisely the public spaces (37\%), followed by the private companies (34\%) and the social organizations (29\%).

Specifically, within the scope of public administration/government, the level they perceive with greater corruption is:

- Higher level/Secretaries of State/Office directors (62\%)

- Low level/bureaucrat/civil servant vs. public (27\%)

- Mid-level/head/Area Coordinator (10\%)

To conclude, having inquired about their perceptions of corruption, corrupt social actors and corruption actions more often, respondents exposed within their proposals to lessen corruption, Following in frequency order:

- Increase the severity of the penalties applied to anyone who performs an act of corruption (68\%)

- Hiring public officials who have high moral integrity and honorability in their professional or technical activity (23\%)

- To increase the educational campaign at national level for the awareness of the law and to act with ethical values (9\%). 
About the knowledge about the different rules and/or laws regulating corruption in Mexico, $72 \%$ mentions ignorance of these laws or norms; The remaining percentage (28\%) says they know them and mentions only in general way the Constitution or the anti-corruption law.

\section{Conclusions}

When we talk about corruption, we must necessarily review the context in which we are developing. In this case, we are dealing with this research in a democratic context; Therefore, we are obliged to answer with the first question, what do we mean by democracy? We can say that, by definition, democracy is based on the confidence to do good for all because it is a system in which a set of individuals are organized, and power is distributed among all citizens. But as Carpizo says (2011), this rarely happens.

Noe then we can define the concept of corruption. Corruption is the practice of abusing power, functions, or means of gaining alegitimate advantage from one another. Profit can be of an economic, political, social nature, among others. According to the Mexican Government secretariat, this can be classified into large-scale, minor and political corruption, depending on the amount of funds lost and the sector in which it occurs (Gob.mx,2019:P.1):

"Minor acts of corruption consist of the daily abuse of power by low-and middle-ranking public officials by interacting with ordinary citizens, who often try to access basic goods and services in areas such as hospitals, schools, Police departments and other agencies.

Political corruption consists in the manipulation of policies, institutions and procedural norms in the allocation of resources and financing by policymakers, who abuse their position to retain their power, Status and Heritage.

About large-scale corruption, this consists of acts committed at the highest levels of government involving the distortion of policies or central functions of the State, and which allow leaders to benefit at the expense of the common good."

The way we perceive our environment is influenced by each one of the elements that understand it. Therefore, the perception and cognitive processes lead us to define what we observe. A more educated citizenry is more skeptical and rigorous in the judgment of its leaders, as well as being more sensitive to ethical issues (Parker, 2008). Schooling is also a determining factor for the development of democratic attitudes, both within and outside the scope of politics. As school levels progress, attitudes and orientations towards democracy also grow (Meyenberg and Flores, 2000: P. 46).

The perception in relation to acts of corruption that violate or preclude democratic processes, is greater in people with higher levels of education.

In the present study the perception of young university students and specifically in vocational training within the law, is clear regarding the presence of acts of corruption in their environment, as well as the social actors most visualized in the exercise of corrupt acts:

- Government agencies are most often perceived as institutions where they are performing corrupt acts and in second place to school.

- The church appears in a fifth place with a moderate presence of acts of corruption, religion was not specified but only the church as an institution.

- The main action of corruption identified is to alter the electricity meter, followed by the presentation of medical evidence. Chiapas is one of the states with the highest electric power production in the country and the rates are equal to or greater than $10 \%$ in the United States, the country to which we export this product.

- The profession or occupation seen as mostly corrupt is that of the politician followed by the policeman.

- The lawyer's profession is placed in a fourth place followed by the priests.

- Most of the respondents have asked, at least once, money to expedite bureaucratic paperwork in government offices; But it is also common for them to offer them for that purpose.

- The highest level/Secretaries of State/office directors are perceived as the level where corrupt acts are mostly performed. 
Even if in the present study, the interviewees are clear that the acts of corruption are carried out in their environment and can even be involved with these, at present we can say that corruption has become institutionalized and have made the existence complex of a democratic country.

The institutionalization of corruption can also cause a high tolerance to it. Today's citizens, immersed in a highly corrupt environment, justify their own actions of corruption perceiving themselves as victims of a system that induces them to carry out such practices (Morán, 2005).

To the extent that they receive what they expected through corruption, they cease to perceive themselves as victims, the psychological costs as guilt and shame fade away and begin to perceive the supposed benefits of corruption (WU and Zhu, 2015).

This can explain what in this research was found in relation to the suggestions that the interviewees have as mechanisms to reduce corruption where it is not considered necessary educational programs for raising awareness the respect of the laws, but rather, the increase of the penalties for the violation to them by acts of corruption.

\section{REFERENCES}

[1] Casar, María Amparo. México: anatomía de la corrupción, CIDE / IMCO, México, octubre de 2016, p.11

[2] CICC (1996). Convención Interamericana Contra la Corrupción, Caracas 29 de marzo de 1996 que entró en vigor en marzo de1997

[3] ONU (2003) Convención de las Naciones Unidas contra la corrupción, celebrada del 9 al 11 de diciembre de 2003 en Mérida, Yucatán, México, y que entró en vigor en diciembre de 2005.

[4] CL (2017). Corporativa Latinobarometro. Junto con Perú, Venezuela, Honduras, Guatemala y Colombia. Informe 2017, Buenos Aires, 2017, p.39. www.latinobarometro.org/LATDocs/F00006433-InfLati nobaro metro2017.pdf

[5] Transparency International (2018). El índice de percepción de la corrupción 2017. Consultado en 13 de diciembre de 2018 en: https://www.transparency.org/news/pressrelease/el_indice_de_ percepcion_de _la_corrupcion_2017_muestra_una_fuerte_presencia

[6] INEGI (2018). Chiapas, pobreza estatal, 2016. Porcentaje, número de personas y carencias promedio por indicador de pobreza. Consultado el 27 de octubre 2018. https://www.coneval.org.mx/coordinacion/ entidades/Chiapas/PublishingImages/Chiapas_Cuadro1.JPG

[7] Castillo, A. y Guerrero, M. A. (s/f). Percepciones de la corrupción en la ciudad de México ¿predisposición al acto corrupto? CIDE y Fundación Ford. Consultado el 22 de noviembre 2018 en: https://www. researchgate.net/publication/266336487_Percepciones_de_la_corrupcion_en_la_ciudad_de_Mexico_predi sposicion_al_acto_corrupto

[8] Carpizo J (2011). La república democrática en la Constitución Mexicana. Boletín de Derecho Comparado, Año XLIV, Núm. 132. Septiembre-diciembre 2011.

[9] Gob.mx (2019). Gobierno de México. Definición de Corrupción. Consultado el 03 de enero 2019 en: https://www.gob.mx/sfp/documentos/definicion-de-corrupcion.

[10] Parker S, Spires P, Farook, F y M Mean (2008). State of Trust. How to Build better Relationships between Councils and the Public. Demos, London.

[11] Meyenberg Y y J Flores. (2000). Ciudadanos y cultura de la democracia: reglas, instituciones y valores de la democracia. Instituto Federal Electoral.

[12] Morán, J. (2005). Blue walls, "grey areas" and cleanups"e: Issues in the control of police corruption in England and Wales. Crime, Law and Social Change, 43, 57-79. doi: 10.1007/s10611-005-3003-1

[13] Wu, Y. \& Zhu, J. (2015). When are people unhappy? Corruption Experience, Environment, and Life Satisfaction in Mainland China. Journal of Happiness Studies, 1-23, doi: 10.1007/s10902-015-9635-7

\section{AUTHORS' BIOGRAPHY}

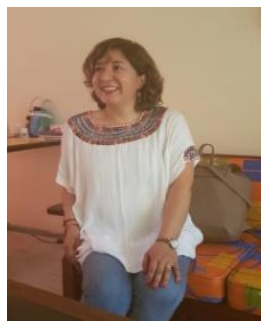

Flor Ivett Reyes Guillén, $\mathrm{PhD}$ and master's in Science from the ECOSUR. Member of the academic corp "Society, culture and education", UNACH. Desirable profile PRODEP. President of the Research Network on public Health and Developmental Problems, REINVESAD. LGAC Society, sustainability and health. Political culture and education. Last three publications: Article: From reasoning to practice: perceptions of sexual health self-care. Published: 26/04/2018 Vol. XIII; No. 7; 522 Portalesmedicos.com ISSN 1886-8924 Book: Coord. Public 
Health, culture and education. ISBN 78-607-8573-29-5 Book Cap: Importance of measuring quality of service in a higher education institution. In Reyes-Guillén FI and AB Palacios Gámaz Coord. 2017. When we talk about a diverse Chiapas. Contributions of the Reinvesad. ISBN 978-607-8459-605

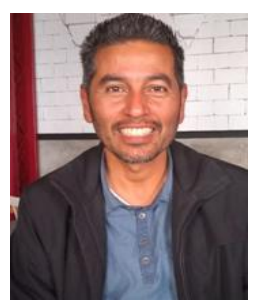

Raúl Vázquez Gutiérrez, Master in community psychology at the University of Chile from 2004 to 2006. Speaker in Congresses in Havana, Cuba and in Santiago de Chile, as well as in different national forums. LGAC "Human rights: sexual and reproductive rights in young people". Books: "HIV/AIDS and sexuality, different looks" edited by the Autonomous University of Chiapas 2012 and "Housewives a anachronistic concept for de XXI century" 2014. Book cap. in" an approach to social science research" 2015. Publication of the master's thesis at the University of Chile in the document "Master's thesis in Community Psychology Compendium Vol. 1".

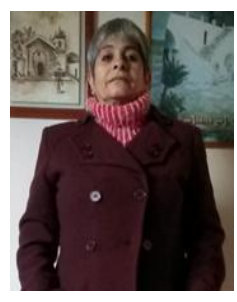

Socorro Fonseca Córdoba, $\mathrm{PhD}$ in Education from the Institute of University Studies, Master's in economics from the National Autonomous University of Mexico. Member of the academic corp "Society, culture and education". LGAC Society, sustainability and health. Political culture and education. Member of the Research Network on Public Health and Developmental Problems, Reinvesad. Publications: Book "School trajectory of the students of the degree in economy generation 2004-2008 in the Faculty of Social Sciences, Campus III, UNACH". Book Cap. IX Ancestry and modernity: the dispute over water in San Cristóbal de Las Casas, Chiapas(COMECSO, 2018) and chapter of X dating violence/couple: Common trunk Faculty of Social Sciences, UNACH (COMECSO, 2018).

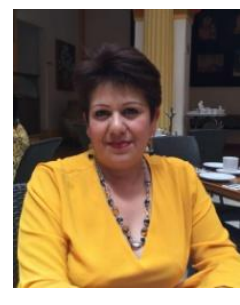

María Angelina Villafuerte Franco, $\mathrm{PhD}$ in Education, Universidad San Cristóbal. Leader of the academic corp Public policy, territory and development. PRODEP profile. Last publications: Chiapas Economy of Poverty, Chiapas, México, UNACH, 2018. ISBN: 9786078459957. Public policies in the territorial dynamics of the State of Chiapas, Chiapas, México, UNACH, 2015. ISBN: 9786078413324. Mexican economy growth or development? Changes, ruptures and continuities in the territorial dynamics of San Cristóbal de Las Casas, Chiapas, Chiapas, Mexico, UNACH, 2013, ISBN: 9786078304042

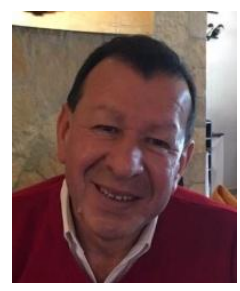

Gustavo Zarate Vargas, PhD in Education, Universidad San Cristóbal. Member of the academic corp Public policy, territory and development. PRODEP profile. Last publications: Chiapas Economy of Poverty, Chiapas, México, UNACH, 2018, (coauthor). ISBN: 9786078459957. Public policies in the territorial dynamics of the State of Chiapas, Chiapas, México, UNACH, 2015, (coauthor), ISBN: 9786078413324. Mexican economy growth or development? Changes, ruptures and continuities in the territorial dynamics of San Cristóbal de Las Casas, Chiapas, Chiapas, Mexico, UNACH, 2013, (coauthor), ISBN: 9786078304042

Citation: Flor Ivett Reyes Guillén et al. "Perception of Young University Students about Acts of Corruption" International Journal of Humanities Social Sciences and Education (IJHSSE), vol 6, no. 1, 2019, pp. 86-92. doi: http://dx.doi.org/10.20431/2349-0381.0601011.

Copyright: (C) 2019 Authors. This is an open-access article distributed under the terms of the Creative Commons Attribution License, which permits unrestricted use, distribution, and reproduction in any medium, provided the original author and source are credited. 